\title{
Financial Leverage and Financial Performance: Empirical Evidence From Listed Textile Industry of Pakistan
}

\author{
Laila Javeed (Corresponding author) \\ PhD Scholar (Finance), School of Finance \\ Zhongnan University of Economics and Law, China \\ E-mail: lailajaveed@hotmail.com
}

Rehana Tabassam

Preston University, Islamabad, Pakistan

Received: December 15, 2018 Accepted: December 26, 2018 Published: December 27, 2018

doi:10.5296/ijafr.v8i4.14136

URL: https://doi.org/10.5296/ijafr.v8i4.14136

\begin{abstract}
The textile sector in Pakistan is the largest manufacturing industry and recognizable model of resistance economy. Over centuries, textile sector has been the country's backbone making available sources of occupation and export returns. Generally, financial leverage is the organizational capability of using borrowed money. It can be described as a fraction, to which a company uses fixed income securities such as debt and equity. The objective of the current study is measuring the impact of financial leverage on firm's financial condition. It is essential to know whether a positive or negative relationship exists between two terms, financial leverage and financial performance of the textile industry; evidence from the listed firms of Pakistani textile industry from 2007-2016. Pooled regression analysis technique shows that there is positive relationship between financial leverage and financial performance (Returns on Assets, Sales Growth and Net Profit Margin). On the other hand, negative relationship exists between Return on Equity ratio. It is confirmed that the organizations have more profitability, might enhance the financial performance having more levels of financial leverage. This study also gives evidence by estimating different facts. It exposes that the main elements of the textile industry in Pakistan enhance their financial performance by employing
\end{abstract}


the financial leverage strategy and can attain a sustainable future growth by making decisions about the selection of their optimum capital structure.

Keywords: Pooled regression, Textile industry, Financial Performance, Leverage, Pakistan stock exchange

\section{Introduction}

Textile is a term come from the "texture" which is a Latin word that means, "To weave". A cloth is manufacture by weaving or knitting forms a fabric. The textile industry is primarily concerned with the production of yarn, cloth and ensuing design or manufacturing of clothes and their distribution. The raw material may be natural or synthetic using products of the chemical industry. The growth of the cotton production and development of textile industry has been remarkable in Pakistan since 1947. At that time there were only six spinning factories in Pakistan, which has now grown up to 503. The main factor behind the growth was reduction in duties. The import tariff on cotton factories was reduced from 85 percent to 50 percent in 1985 and then 20 percent in 1988. In 1988, the restrictions on renewal and expansion of spinning and weaving factories were removed too.

In Pakistan, the largest manufacturing industry is the textile sector, and certainly, it is a demonstrable of a resistance economy. Intended for eras, the textile sector has been country's backbone as it offered bases for employment and export opportunities. On the other hand, it is facing tough competition in international market due to increase in the cost of production; which is making it less competitive than the neighboring countries like Bangladesh, India, and China. Textile sector is contributing 57 percent in exports of Pakistan. It is the second largest employment sector in Pakistan and exporter of textile merchandises in Asia. The textile sector contributes 8.5 percent to the GDP of Pakistan. It is appropriate to indicate that the exports of textile products conducted a growth of 12.8 percent year-on-year to 4.4 billion US dollars in 2017-18.

The fourth largest country of cotton grower in the world behind China, India and U.S.A is Pakistan. The textile sector has become the most important industry for earning foreign exchange. It accounts for almost 65 percent of foreign exchange earned in a year, which is approximately 5.5 billon US dollar. Pakistan's economy greatly depends on the sector of textile industry. Nearly, half of the country's manufacturing base is the cotton-processing and textile industries framework. Whereas cotton is Pakistan's main industrial yield, contributing acute wages to rustic households. Overall, the cotton-textile sectors account for 11 percent of GDP and 60 percent of export revenues.

According to the economic survey of Pakistan 2008-09; the textile industry of Pakistan, backs more than 60 percent to the country's total exports amounting around 5.2 billion US dollars. According to the economic survey of Pakistan 2012, issued by the finance ministry, the textile industry itself constituted about 4 percent of the total economy. The current situation of the textile industry is not very encouraging. The progression of cotton has improved in the current period; furthermore, electricity and sale taxes have increased too. The price of cotton yarn is declining and further involvement costs are cumulative. Generally, it is belief that the 
financial leverage has affected performance of the firm. This study measures the relationship between financial leverage and financial performance of the listed industries of textile sector in Pakistan. The research will investigate the effect of financial leverage on financial performance of the textile sector and explore whether financial leverage has an influence on the financial performance by taking evidence from listed firms of Pakistan's textile sector.

The textile sector serves as a backbone for the economy of the Pakistan on the way towards a sustainable economic development. The research conducted for recognizing the financial leverage that influence the financial performance of the industries' will support them to know about the outcomes and increase the profitability taking into account the selection of leverage, if it esteems to form a significant positive effect on financial performance.

The financial leverage is the proficiency of an institution in order to use borrowed money. It can be described as a proportion to which an organization uses fixed income securities; for example equities and debts. When financial leverage increased, as a result financial cost of the organizations also increased. Because of high finance, cost earning per share is negatively exaggerated. High interest payments affect EPS negatively. Several studies have showed positive relationship between financial performance and financial leverage while other shows negative relationship. The basic purpose of current research is to find out the relationship between financial performance and financial leverage of the textile sector in Pakistan too.

The little research has done on the effects of financial leverage and financial performance of the firms in Pakistan. Therefore, there is need and worth of this research in Pakistan. The financial leverage is taken as the performance promoter in the country ,but they are unaware about the statistics worth of investment interrelated with financial leverage can have negative influence on the profitability of the firm plus it can also hit the earning per share of investors if value of investment increases more that profitability of the industry. Now to understand the ensuing facts, this research will be very helpful for the textile industry to assess their economic requirements and to what capacity they should employ leverage, to have favorable returns for shareholders and to gain a healthy performance. In this research, 110 listed firms as a sample size has been selected from the textile sector of Pakistan stock exchange.

This research is conducted to observe the relationship between financial leverage and financial performance. The dependent variable used in this research is financial leverage which will be measured by debt to equity ratio while the Independent variables used are financial performance of listed textile industries at Pakistan stock exchange. Independent variable will be measured by using ratios ROA, Net Profit Margin, ROE, Sales Growth and ROCE. Outcomes will indicate the association between financial leverage and financial performance of the industry. This research will be very helpful for the firms to analyze their financial needs, capability to develop and in what manner it is beneficial for generating revenues for investors and finally for financial development of Pakistan. 


\section{Review of Literature}

In the empirical literature, Ali (2014) engaged a sample of 20 companies of chemical sector listed on Karachi stock exchange. The research was conducted to observe the relationship between financial leverage and financial performance of listed chemical companies .The study got a positive relationship between financial leverage and financial performance by accepting alternate hypothesis $\mathrm{H} 1$ and rejecting null hypothesis Ho. In this, research the financial leverage used as dependent variable that has measured by using debt to equity ratio while the financial performance of listed chemical companies used as Independent variable that had measured by using ratios return on assets, return on equity, net profit margin, and Return on capital employed. The values indicated positive relationship of ROA, Net Profit Margin and Return on Capital Employed with debt to equity ratio, but negative relationship of Return on Equity with debt to equity ratio. Regression results of the study showed a negative adjusted R-square in ROA, ROE, and net profit margin while it is positive in Return on Capital Employed .In the situation of Net Profit mean probability was slight higher, though standard deviation of ROA, and ROE were bottommost. In the case of descriptive, statistic standard deviation was maximum. Hence, null hypothesis had rejected and the alternate hypothesis that there was positive relationship between financial leverage and financial performance had accepted.

According to the Cheng and Tzeng (2014) used the sample of 645 firms that were listed in Taiwan Securities Exchange (TSE) from 2000-2009. The study applied a least square dummy variable model to evaluate the influence of leverage on the market value of the firms. Firstly, they determine that the values of leveraged firm are more than that of an unleveraged firm if we do not figure out the possibility of bankruptcy. Secondly, if directly, we consider the value and cost of liability, the leverage is significantly positively affect the value of firms formerly reaching firm optimal capital structure. Thirdly, the positive influence of leverage to the firm value tends to be stronger when the firm financial worth is improved. These outcomes make available insight into firms' debt financing decisions, supporting firms to capitalize on their standards.

Al-Tally (2014) investigated the effect of financial leverage on firm's financial performance in Saudi Arabia. The research was develop to extend understandings in the literature of in what way financial leverage works in a financial structure that was interest free, and how it can distract the financial performance. This study observed 57 publicly trading firms listed in the Saudi Arabian stock market from (2002-2010). The research had extends the understandings before stated in the previous work of in what way financial performance has associate with financial structure, zakat (Islamic tax), and the ages and sizes of Saudi Arabian firms in an interest free financial system. A great supporter of this research was the 2006 Saudi Arabia stock market calamity and the 2008 global economic crisis, which lowered the trades' certainty on the finances from the bank as per a source of fund. The study concluded that in the long term in the skiving of critical financial crisis, lesser leverage have a tendency to initiate greater revenues on both assets and equity and leads to advanced profit margins. Similarly, it had carried the evidence that firms in Saudi Arabia can effort to improve their economic performance by balancing their obligations of zakat with leverage borrowing trends. 
A separate study is essential to observe the special effects of zakat on capital structure and financial performance for each area might provide complete information about this correlation.

A research had been conducted by Obradovich and Gill (2013) on the impact of corporate governance and financial leverage on the value of American firms. The sample of study consisted of 333 firms listed on New York Stock Exchange from 2009-2011. The co-relational and non-experimental research design practiced to conduct this research. The firm value had taken as dependent variable and financial leverage, CEO duality, board size and audit committee as independent variables while firm size, ROA and insider holdings used as control variables. Overall, outcomes of the study indicated that the value of American firms, negatively affected by huge size of board, while the other factors which consist of CEO duality, audit committee, financial leverage, firm size, return on assets, and insider holdings positively affect the value of American firms. The effect of corporate governance and financial leverage varies among manufacturing and service industries. The consequences also indicate that board size negatively affects the value of American service firms, in consort with financial leverage and returns on assets positively affect the value of American service firms. This research approves the literature on the aspects that upset the value of firm. The findings of this study might be valuable for financial managers, stockholders, and specialists of the economic organization.

Rehman (2013) employed a sample of 35 listed companies from food producer sector of Karachi stock exchange. The listed sugar companies were included in the research from the food producer sector of Karachi stock exchange and all the other companies were eliminate from the study. The research was conduct to find out the relationship between financial performance and financial leverage. The main variable used for test of hypothesis consist of independent variable that is financial leverage measured by the ratio of debt to equity while dependent variable is financial performance of sugar companies listed at KSE, which were measured by using of return on asset, return on equity, earning per share, net profit margin and sales growth. Outcomes of the study show mix results. There was positive relation of debt to equity ratio with Return on Asset and Sales Growth and negative relationship of debt to equity ratio with Earning per share return on equity and Net Profit Margin. As a result, Sugar Companies listed at Karachi Stock Exchange can improve their financial performance by taking leverage up to a level of significant besides be capable of specify their measures in enhancing the economy of the country.

The evaluating effects of financial leverage on future stock value at stock exchange had studied by Hasanzadeh et al., (2013). The investigation statistical sample was comprised of those Tehran stock exchange listed dynamic cement industry companies evaluated from 2005 to 2008. To assess the existing research and test hypothesis, financial leverage and market to book value ratio taken as variables, descriptive and inferential analyzing methods and SPSS statistical software were applied. They determined that future stock value of the firm does not affected by leverage. The consequences indicate non-response of capital market compared to levered nature of the firm. Incompetence of association between leverage and firm value favor net operational income (NOI) theory14, Miller and Modigliani (M.M) theory 15. 


\section{MlMacrothink}

International Journal of Accounting and Financial Reporting

ISSN 2162-3082

2018, Vol. 8, No. 4

The impact of influence on shareholders return had studied by (Akhtar et al., 2012; Nazir et al., 2016). They engaged a sample of 20 listed public limited companies from fuel and energy sector listed at Karachi Stock Exchange (KSE). To test the hypothesis, the main variables used in the study consist of a dependent variable that is financial performance of fuel and energy sector while an independent variable financial leverage in fuel and energy sector. In their research" relationship between financial leverage and financial performance: Evidence from fuel \& energy sector of Pakistan, they verified that financial leverage has got a positive relationship with financial performance". Therefore, the companies in the fuel and energy sector can develop their financial performance besides know how to perform their part for the developing of the economy although clarifying at their prime structures of investment. The research intended for determining the relationship between financial leverage and the financial performance. Over-all outcomes exposed the positive relationship between financial performance and financial leverage. Therefore, fuel \& energy sector companies in Pakistan can have viable outcomes while affecting in terms of leverage.

The influence of financial leverage on corporate performance of some organizations in Nigeria had researched by Ojo (2012). He tried to relate preceding findings that were specific of formed states. The econometric technique of Vector Auto Regression (VAR) model had selected to examine the influence of power on earning capacity \& evidently the performance capability of corporate firms. Data had used between the years $(1993$ - 2005). The VAR model was designed for two engaged variables, leverage was measured by condition of value and proportion of firms \& net asset spoke to corporate execution for every offer and EPS. The outcomes verified that leverage shocks have substantial effect on corporate execution mainly when net asset for each share operated as an Indication of corporate execution in Nigeria completed the Time accessible by the research. Similarly, uncovered leverage stun on EPS directly affects net asset for every share of firm as per heft of stuns on NAPS obtained from EPS of firm. Capture Vector has assured with net asset for each agreement although it is negative with EPS and impact. The particular explanations on effect investigated in created states would not be acceptable proxies for such conduct in Nigeria and not used to simplify the empirical elements in the creating states on the sphere. Thus, the significance of aboriginal opinions cannot be emphasizing.

The effect of financial leverage on shareholders return and market capitalization had investigated by Saini (2012). The empirical evidence of telecommunication sector companies, India. To measure this, financial statements of seven listed firms have been investigated over a period of seven years. Descriptive Statistics, Co-relation and t-test has been conducted to find out nature of relationship and the state of influence of the financial leverage on shareholder's return and market capitalization individually. The outcomes show that there is positive relationship between financial leverage and shareholder return but negative relationship between financial leverage and market capitalization.

The impact of financial leverage on dividend policy evidence from listed companies at Karachi stock exchange, observes the relationship between dividend policy \& the financial leverage of 403 companies, listed in the Karachi stock exchange during the period 2002-2008 (Asif et al., 2011). The findings of the study concerning the approach for the profit that is 
lagged by the organizations is tried by developing broadened model of Linter (1956) .Data utilized for this research had been gathered from analysis reports, online statistics base of global stock data, annual reports of the listed firms, website of state bank of Pakistan. Dividend yield and debt ratio were use as independent variable and dividend per share as dependent variables. Initially, descriptive statistics for all the variables then framework of association had thought to differentiate a preliminary correlation of the variables compete with setback analysis on panel evidence to explore the level and precarious through stable and asymmetrical effect model. It had confirmed through theoretical verifications and had secured through random impact display that mostly accomplished disbursement attitude also level of corporate requisite that affect the returns intention of Pakistani firms. However, it had been perceive that financial leverage found to have negative effect overhead of income, indicating that a lesser amount of revenue, reimbursements are complete by the institutions that are underneath high leverage.

According to the Moradi et al., (2010) showed the effect of financial leverage on earnings response coefficient through income approach. The research include organizations recorded on Tehran stock exchange and the data of seven year period from 2002-2008 was used. Financial leverage and unexpected earnings has taken as independent and abnormal stock return as dependent variable. The empirical evidence of Iranian intention to observe correlation between budgetary influence and profit reaction coefficient through a wage approach. The corporations increase their significance by unique structures to give the optimal that provide superior practices are a test that most money interrelated directors of the partnership face. The institutions with significant compulsion, the reaction of stock costs to unexpected income will be effect by business's insolvency threat. In this research, analysis of data was performed by using multiple regressions. The consequences of the study reveals that the profit reaction coefficient for the low authority firms gathering is better than greater affect ones, with contrasts in the approaches between meetings exactly remarkable.

Bhatti et al., (2010) examined the effect of leverage on stock returns and systematic risk in the corporate sector of Pakistan. The paper had struggled to make an analysis on the influence of power on effective threat and stock return in the corporate sector of Pakistan. Primary data had gathered from eight commercial enterprises that are cotton, designing, fuel and vitality, chemicals, transport and correspondence, sugar and partnered concrete, paper \&board from the period 2005-2009. Investigators evaluated the data by using the ways of return, standard deviation, and leverage and connected this whole process in MS Excel. Outcomes provided that although of various reorganizations carried by the Government, corporate part still take an irregular state of inspiration creating irregular state of systematic hazard encouraging great uncertainty in stock costs of these marketable projects traded on Karachi stock exchange.

An empirical insight into the relationship between Return on Equity (ROE), financial leverage and size of firms in the restaurant industry for the period 1998 to 2003 studied by Yoon and Jang (2005). Using OLS regressions and for this purpose they take 62 Restaurant firms in US. The outcomes of the study showed that high leveraged firms were less risky in both market- based and accounting-based measures. There is positive relationship between financial leverage and both profit measures are positively correlated. As well, recommend 


\section{MlMacrothink}

International Journal of Accounting and Financial Reporting

ISSN 2162-3082

2018, Vol. 8, No. 4

that at least throughout the test period firm size had a prevailing effect on ROE of restaurant firms than debt use, larger firms earning meaningfully higher Equity Returns. Consequences also recommend that regardless of having lower financial leverage, smaller restaurant firms were significantly more risky than larger firms.

The significance of leverage in investment portfolios is to borrow at a cost of capital lower than the return at which the capital can be reinvested. Companies use financial leverage to generate flexibility, retain access to capital markets, and buy back equity, besides finally form the value of stakeholder. The policies and approaches are vary from company to company but are always methodically associated to the overall intentions of the organization's Garrison et al., (2004).

\section{Conceptual Framework and Hypothesis Development}

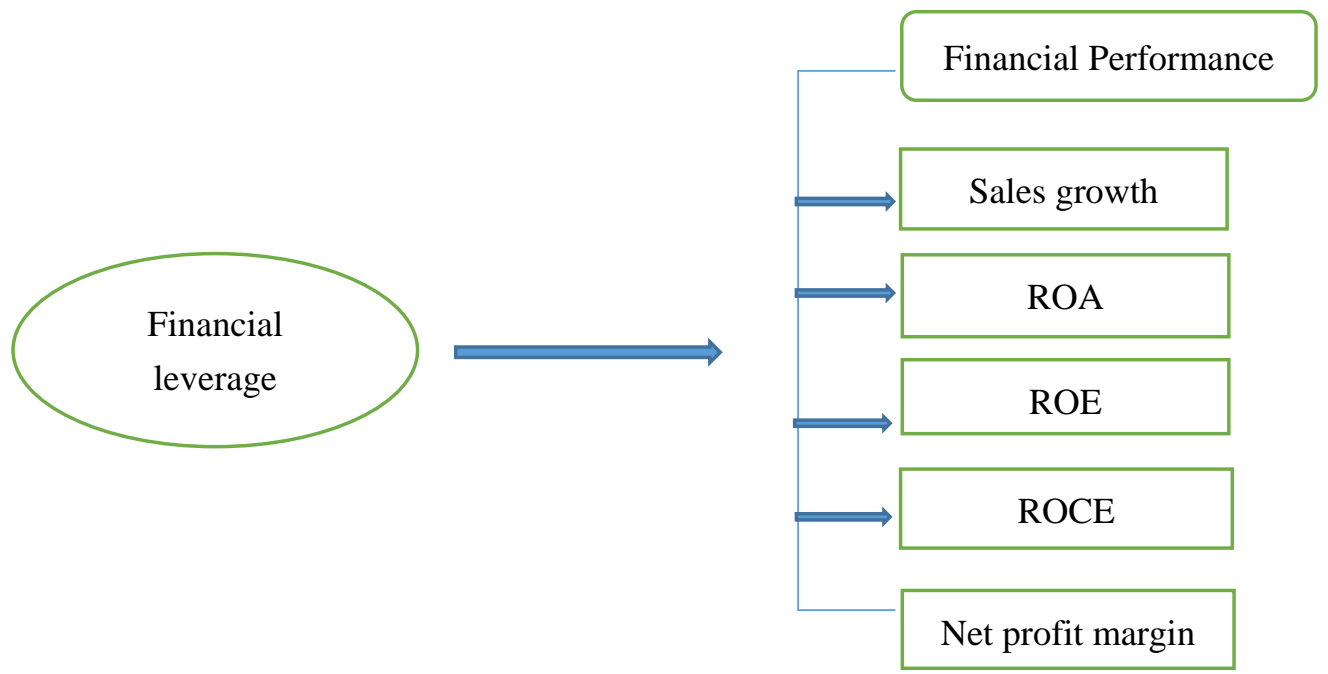

$\mathrm{H}_{1}$ : There is a positive relationship between financial performance of the textile sector and the financial leverage.

$\mathrm{H}_{0}$ : There is a negative relationship between financial performance of the textile sector and the financial leverage.

\section{Sample and Data Description}

The study is a quantitative research comprising an empirical practice between several variables. The sample size consists of 110 firms from textile sector listed at Pakistan Stock Exchange (PSE) for the period of ten years 2007 to 2016. The Secondary data has been used for this research, as stated by the Kothari (2004) secondary data consist of published or unpublished data of financial reports. Because secondary data is not expensive and time consuming as compared to qualitative research, so researcher preferred secondary source of data. The researcher has an opportunity to gather well worth data Leedy and Ormrod (2005); Brynjolfsson and Saunders (2009). The data for control variables and dependent variables attained from OSIRIS database, derived from the firm's financial statement, and was transformed in to percentages and ratios. The data for independent variables have taken out from firm's financial statements provided by State Bank of Pakistan. Furthermore, annual 
reports of listed firms also accessed to deal with the missing values of firm performance variables.

The general form of the model:

Financial leverage $=\mathrm{f}(\mathrm{SGT}, \mathrm{ROA}, \mathrm{ROE}, \mathrm{ROCE}, \mathrm{NPM})$

The econometric form of the model:

$$
D E R_{i t}=\alpha_{0}+\alpha_{1} S G T_{i t}+\alpha_{2} R O A_{i t}+\alpha_{3} R O E_{i t}+\alpha_{4} R O C E_{i t}+\alpha_{5} N P M_{i t}+\varepsilon_{t}
$$

In this model, dependent variable is DER representing debt to equity ratio, while independent variables are Sales Growth, Return on Assets, Return on Equity, Return on Capital Employed and Net Profit Margin.

\subsection{Measurement of Variables}

In this study, we used leverage as a dependent variable that is measured by debt to equity ratio. The financial performance of the firms will be measured by using the basic indicators namely Returns on Assets (ROA), Return on Equity (ROE), Return on Capital Employed (ROCE), Sales Growth and Net Profit Margin. Descriptive statistics is used to describe and summarize the performance of the variables in this research. The correlation and pooled regression analysis has been conceded to observe the relationship concerning financial leverage and financial performance of the textile sector.

\subsection{Empirical Results and Discussion}

This section contains the empirical investigation of the financial leverage and the financial performance. The general method to calculate the financial leverage is to use the financial ratio, in this care the debt to equity ratio is being calculated and investigated. This ratio is calculated by dividing the total liabilities to total shareholders' equity fund. This ratio shows that how much portion of the capital structure is being financed by the external sources. In the listed companies of Pakistan, the debt equity ratio 0.5069, the maximum value of this ratio is 0.8866 , and the minimum value of this ratio is 0.2715 .

This standard deviation of the debt to equity ratio is 0.2009 . Table 1 shows the descriptive statistics of the financial performance (Return on assets, Return on equity, Return on capital employed, Net Profit Margin, and the Sales Growth). The maximum value of the Return on Assets is 0.1342 and the minimum value is 0.0335 . The industrial average of the Return on Asset is 0.0708 with the standard deviation from the mean is 0.0330 . The return on equity is also important factor to influence the financial leverage. The average value of the Return on Equity is 0.1171 , with the maximum value of 0.2140 and the minimum value is 0.0558 . The maximum value of the Return on Capital Employed is 22.7700 and minimum value is 8.3100.

The industrial average of the Return on Capital Employed is 14.5430. The average value of the Net Profit Margin is 14.8960, with a maximum value of the 32.1200 and the minimum value is 8.2900. It means that the all of the firms have positive performance for the time period. The maximum value of the sales growth is 0.1321 and the minimum value is -1.2080 . 


\section{Ml Macrothink}

International Journal of Accounting and Financial Reporting

ISSN 2162-3082

2018, Vol. 8, No. 4

The mean value of the industrial Sales Growth is -0.1848 with the standard deviation from the mean is 0.3760 . Table 2 shows the correlation relationship between the financial leverage and the indicators of the financial performance. All of the indicators of the financial performance are positively associated with the financial leverage, except the Sales Growth and the Net Profit Margin. Moreover, there is no multicollinearity problem, because all of the value is less than the rule of thumb value that is the 0.80 .

Table 3 shows the pooled regression results with the five different models. The first model contains all the indicators of the financial performance (Return on Assets, Return on Equity, Return on Capital Employed, Net Profit Margin, and Sales Growth). In addition, all the remaining models show the individual effect of the indicators of the performance on the debt to equity ratio. The Net Profit Margin shows that how much additional earning by the organizations has influence on the firm performance. The positive relationship between the debt equity ratio and the Net Profit Margin ratio shows that as the debt equity ratio rises, the Net Profit of the organizations tend to the increases. This is also depends on the managerial strategy that how they finance through the debt or equity. The positive and statistical significant relationships between the financial leverage and the Return on Assets, which are financed by the debt, have more returns. On the other hand, the Return on Equity has also significant effect on the financial leverage for the industrial sector of Pakistan.

At the same time the economic conditions also influenced on the financial leverage. If the company manager have more focus on the debt option, then it is also good for the Return on Equity when the economic conditions are favorable, but if the economic condition is not good, then rise the debt option might deteriorate the performance of the particular organizations. The financial leverage also influence theoretically on the return on equity. It may be positively or negatively affected on the financial leverage and to the productivity in the use of the debt financing. This can be apprehended under the conditions that used the debts be on time, which the lower interest, lowers costs, and through the effective using them. The result also shows the positive influence of sales growth on the financial leverage of listed firms of Pakistan textile industry. The F-statistics value is also significant which means the overall model is also good. In the main model the coefficient of determination is 0.8404 , which means that $84 \%$ of the variation explained by the explanatory variables to the financial leverage.

Table 1. Descriptive statistics

\begin{tabular}{lllll}
\hline Variables & Mean & Max & Min & Std.Dev \\
\hline DER & 0.5069 & 0.8866 & 0.2715 & 0.2009 \\
\hline ROA & 0.0708 & 0.1342 & 0.0335 & 0.0330 \\
\hline ROE & 0.1171 & 0.2140 & 0.0558 & 0.0592 \\
\hline
\end{tabular}




\begin{tabular}{lllll} 
ROCE & 14.5430 & 22.7700 & 8.3100 & 4.7380 \\
\hline NPM & 14.8960 & 32.1200 & 8.2900 & 7.5575 \\
\hline SGT & -0.1848 & 0.1321 & -1.2080 & 0.3760 \\
\hline
\end{tabular}

DER is the debt to equity ratio, ROA is the return on assets, ROE is the return on equity, ROCE is the return on capital employed, NPM is the net profit margin, and the SGT is the sales growth. Max is the maximum value, Min is the minimum value and Std.Dev is the standard deviation.

Table 2. Correlation matrix

\begin{tabular}{lllllll}
\hline Variables & SGT & ROE & ROCE & ROA & NPM & DER \\
\hline SGT & 1.0000 & & & & \\
\hline ROE & -0.5446 & 1.0000 & & & & \\
\hline ROCE & -0.1970 & 0.6589 & 1.0000 & & & \\
\hline ROA & -0.4169 & 0.7107 & 0.6916 & 1.0000 & & \\
\hline NPM & -0.5162 & 0.3264 & 0.6565 & 0.6589 & 1.0000 & \\
\hline DER & -0.5600 & 0.2621 & 0.1605 & 0.0474 & -0.0702 & 1.0000 \\
\hline
\end{tabular}

DER is the debt to equity ratio, ROA is the return on assets, ROE is the return on equity, ROCE is the return on capital employed, NPM is the net profit margin, and the SGT is the sales growth. Max is the maximum value, Min is the minimum value and Std.Dev is the standard deviation.

Table 3. Pooled regression results

\begin{tabular}{|c|c|c|c|c|c|c|}
\hline Variables/Model & Model 1 & Model 2 & Model 3 & Model 4 & Model 5 & Model 6 \\
\hline \multirow[t]{2}{*}{ SGT } & $0.1688 * *$ & $0.2992 * *$ & & & & \\
\hline & $(0.0246)$ & $(0.0140)$ & & & & \\
\hline \multirow[t]{2}{*}{ ROE } & $-17.0462 * *$ & & $-0.8886 * *$ & & & \\
\hline & $(0.5793)$ & & $(0.1040)$ & & & \\
\hline ROCE & -0.0021 & & & 0.0068 & & \\
\hline
\end{tabular}




\begin{tabular}{lllllll}
\hline ROA & $\begin{array}{l}31.7638^{* *} \\
(1.0114)\end{array}$ & & & & $0.2882^{*}$ \\
& & & & $(0.1930)$ \\
NPM & $0.0167 *$ & & & $0.0018^{*}$ \\
& $(0.0015)$ & & & & $(0.0008)$ \\
\hline CON & $0.5731^{* *}$ & $0.4516^{*}$ & $0.4028^{* *}$ & $0.4079^{*}$ & $0.4865^{* *}$ & $0.5347^{* *}$ \\
& $(0.0141)$ & $(0.0058)$ & $(0.0136)$ & $(0.0203)$ & $(0.0150)$ & $(0.0140)$ \\
\hline OBS & 1100 & 1100 & 1100 & 1100 & 1100 & 1100 \\
\hline Adjusted R & 0.8404 & 0.3130 & 0.0678 & 0.0257 & 0.0249 & 0.0401 \\
\hline F-Statistics & 1159.401 & 501.794 & 81.0353 & 29.0458 & 24.7452 & 5.4445 \\
(Prob. Value) & $(0.0000)$ & $(0.0000)$ & $(0.0000)$ & $(0.0000)$ & $(0.0000)$ & $(0.0198)$ \\
\hline
\end{tabular}

DER is the debt to equity ratio, ROA is the return on assets, ROE is the return on equity, ROCE is the return on capital employed, NPM is the net profit margin, and the SGT is the sales growth. Max is the maximum value, Min is the minimum value and Std.Dev is the standard deviation. Model 1 is the main model with all financial performance indicators, and the remaining model ( 2 to 6 ) is to take the individual indicator of the financial performance to check the individual effect.

\section{Conclusion}

The main objective of this paper is to examine the relationship between financial leverage and financial performance by employing a sample of the Pakistani textile firms listed on the Pakistan Stock Exchange for the period 2007 to 2016. Therefore, the textile sector may enhance their financial performance and can play their role for the growth of the economy while improving at their optimal capital structures. For the success of any organization, the key element is financing decision. The financial leverage is the degree to which an organization uses the fixed-income through various securities such as the equities and debts. The firm should keep its best capital structure in mind when making the financing decision to confirm any increases in equity and debt to enhance the return of the business. The decision of financial leverage is critical for survival and performance of the organizations. Therefore, the appropriate debt to equity mixture should be adopted by the organizations if they should develop their financial performance, continue to exist and remain the competitive. Then it may translate the financial leverage into profitability and value maximization of the textile sector in Pakistan in long run. The textile sector can play an important function in the uplift of the economy by reviewing its capital structure priorities. By implying the pooled regression technique, the result of this study shows the positive relationship between financial 
leverage and financial performance (Return on Assets, Sales Growth and Net Profit Margin), but the negative relationship with the Return on Equity. It means that increase in debts in capital structure will result in declining the financial performance as measured by ROE. However, the organizations should use a suitable proportion of debt to equity in its capital structure if the ROE is to be enhanced. The employment of debt in the capital structure of the industry may make a positive impact on the performance. In order to maximize the return on investment leverage may be used as making considerations to improve at financial position of the companies by raising their financial performance. Pakistani firms are recommended to insert the specific amount of equity to enhance the capital structure along with the leverage ratios. In addition to concentrating on matching of liabilities with the different type of assets they own (which is short term borrowing to be attained solely for the purpose of working capital).

\section{References}

Akhtar, S., Javed, B., Maryam, A., \& Sadia, H. (2012). Relationship between financial leverage and financial performance: Evidence from fuel \& energy sector of Pakistan. European Journal of Business and Management, 4(11), 7-17.

Ali, M. (2014). Relationship Between Financial Leverage and Financial Performance (Evidence of Listed Chemical Companies of Pakistan). Research Journal of Finance and Accounting, 5(23), 46-56.

Al-Tally, H. A. (2014). An investigation of the effect of financial leverage on firm financial performance in Saudi Arabia's public listed companies. Victoria University.

Asif, A., Rasool, W., \& Kamal, Y. (2011). Impact of financial leverage on dividend policy: Empirical evidence from Karachi Stock Exchange-listed companies. African Journal of Business Management, 5(4), 1312-1324.

Bhatti, A. M., Majeed, K., Rehman, I., \& Khan, W. A. (2010). Affect of leverage on risk and stock returns: evidence from Pakistani companies. International Research Journal of Finance and Economics, 58, 32-49.

Brynjolfsson, E., \& Saunders, A. (2009). Wired for innovation: how information technology is reshaping the economy. MIT Press.

Cheng, M.-C., \& Tzeng, Z.-C. (2014). Effect of leverage on firm market value and how contextual variables influence this relationship. Review of Pacific Basin Financial Markets and Policies, 17(1).

Garrison, D. R., \& Kanuka, H. (2004). Blended learning: Uncovering its transformative potential in higher education. The Internet and Higher Education, 7(2), 95-105.

Hasanzadeh, R. B., Torabynia, S., Esgandari, K., \& Kordbacheh, S. (2013). Evaluating Effects of Financial Leverage on Future Stock Value at Stock Exchange. Research Journal of Recent Sciences, 2(2), 81-84.

Kothari, C. R. (2004). Research methodology: Methods and techniques. New Age 


\section{Al Macrothink}

International Journal of Accounting and Financial Reporting

ISSN 2162-3082

2018, Vol. 8, No. 4

International.

Leedy, P. D., \& Ormrod, J. E. (2005). Practical research. Pearson Custom.

Moradi, M., Salehi, M., \& Erfanian, Z. (2010). A Study of the Effect of Financial Leverage on Earnings Response Coefficient through out Income Approach: Iranian Evidence. International Review of Accounting, Banking and Finance, 2(2), 104-116.

Nazir, M. I., Zulfiqar, M., Saeed, M. B., \& Habib, Y. (2016). The Influence of Board Characteristics on Shareholders Assessment of Risk for Small and Large Firms: Evidence from Pakistan. International Journal of Economics and Financial Issues, 6(2).

Obradovich, J., \& Gill, A. (2013). The impact of corporate governance and financial leverage on the value of American firms.

Ojo, A. S. (2012). The effect of financial leverage on corporate performance of some selected companies in Nigeria. Canadian Social Science, 8(1), 85-91.

Rehman, S. S. F. U. (2013). Relationship between financial leverage and financial performance: Empirical evidence of listed sugar companies of Pakistan. Global Journal of Management and Business Research.

Saini, R. (2012). Impact of financial leverage on shareholders returns and market capitalization: empirical evidence of telecommunication sector companies, India. International Journal of Research in IT, Management and Engineering, 2(12).

Yoon, E., \& Jang, S. (2005). The effect of financial leverage on profitability and risk of restaurant firms. The Journal of Hospitality Financial Management, 13(1), 35-47.

\section{Copyright Disclaimer}

Copyright for this article is retained by the author(s), with first publication rights granted to the journal.

This is an open-access article distributed under the terms and conditions of the Creative Commons Attribution license (http://creativecommons.org/licenses/by/4.0/) 